\title{
First application of the QBS-ar Index in South America for the assessment of the biological quality of soils in Chile
}

\author{
Loris Galli ${ }^{1 *}$, Elisa Lanza ${ }^{1}$, Ivano Rellini ${ }^{1}$ \\ ${ }^{1}$ Department of Earth, Environmental and Life Sciences (DISTAV), Genoa University, Corso Europa 26 - 16132 Genoa, Italy \\ * Dr L. Galli, loris.galli@unige.it, ORCID iD: http://orcid.org/0000-0002-8920-8881
}

Received: 29.11.2020

Accepted: 21.04.2021

Associated editor: A. Józefowska

Keywords
Biotic index
Coyhaique National Reserve
Grassland
Nothofagus spp. forest
Pinus spp. forest
Soil arthropods

\begin{abstract}
The QBS-ar (Biological Quality of Soil, based on arthropods) index was applied in Coyhaique National Reserve (Chile). The aims of our research were to assess the abundance and diversity of soil microarthropods in different South American habitats, evaluating to what extent chemical parameters and seasonal changes of weather conditions can affect these organisms. Moreover we wanted to verify if the QBS-ar index was applicable in the Neotropical biogeographic region in order to distinguish between habitats subject to different levels and types of disturbance. Therefore, four habitats were investigated: primary native Nothofagus spp. forest (OG), native forest of secondary growth after fires (SG), reforestation pine forest (PI) and anthropogenic grassland (PR). During each of seven sampling sessions (nearly one every 10 days) between October and December 2017, five 1 liter soil cores were collected in each habitat. Microarthropods extracted by means of Berlese-Tullgren funnels were counted, identified to the order level and evaluated based on their morphological adaptation to life in soil in order to assess QBS-ar values and related quality classes. Both microarthropod communities and QBS-ar values comparisons showed that OG and SG forests are close to each other, and the same is true for PI and PR. Soils of the former couple of habitats were characterized by a much higher biological quality level with QBS-ar values of $129.1 \pm 20.2$ and $111.8 \pm 6.4$, respectively, both corresponding to the quality class 6 (out of a maximum of 7). On the contrary, PI and PR scored QBS-ar values of $83 \pm 13.5$ and $80.3 \pm 10.8$, respectively, and quality classes ranged between 3 and 4. Relationships among dominant and subdominant microarthropod taxa and environmental variables were analysed. In particular some chemical properties of soils $\left(\mathrm{pH}, \mathrm{CaCO}_{3}, \mathrm{~N}_{\mathrm{t}}\right.$, soluble $\mathrm{P}$, exchangeable $\mathrm{K}$, organic matter, $\mathrm{C} / \mathrm{N}$ ratio) and weather variables (cumulated rainfalls and mean temperatures during the 7 days before each sampling session) were considered. This is the first time the QBS-ar index has been applied in the Southern Hemisphere. Our results seem to indicate this index can be "exported" also to South America, resulting a useful tool for a user friendly assessment of the impact on terrestrial environments by different forms of disturbances and of habitat management.
\end{abstract}

\section{Introduction}

Soil is one of the most species-rich habitats (Wolters, 2001), representing the decomposition subsystem of terrestrial ecosystems. Soil reflects terrestrial ecosystem metabolism since all the bio-geo-chemical processes of the different ecosystem compartments fall on it; therefore, soil quality assessment can be considered a suitable criterion for evaluating the health status of an ecosystem. The biocenosis of soil mainly depends on the contribution of organic matter (e.g. undecayed plant and animal residues) from the epigeal subsystem and its role is the degradation of such matter in order to make available mineral nutrients $(\mathrm{N}$, $\mathrm{P}, \mathrm{K}$ ) to plants (Wardle, 2002; Murphy, 2014). This apparently simple cycle is strictly linked to the sequestration of large amount of carbon and, therefore, soil management and conservation can be considered of global interest from many points of view, from the regulation of climate processes to the productivity of agroecosystems (e.g. Lal, 2004; Lajtha et al., 2018; Ondrasek, et al., 2019). Soil organic carbon (SOC), in fact, plays an important role in the overall $\mathrm{C}$ cycle, and even small changes in the SOC stock can influence the greenhouse gas concentrations in the atmosphere (Breuning-Madsen et al., 2009; Brevik, 2012). For this reason, the Kyoto Protocol accounts for this important element in the management of greenhouse gas emissions (Ruiz Sinoga et al., 2011). SOC is sensitive to a range of factors, including climate, topography, soil and vegetation management, among other anthropogenic factors (Tan et al., 2004). In particular, Paustian et al. (1997) highlighted that the SOC content decreases with 
increasing soil disturbance, reaching higher concentrations in areas with little soil disturbance and in forested environments. Moreover, the SOC storage is influenced by temperature and moisture regime (Fantappiè et al., 2010). The SOC sequestration decreased from the field sites with humid conditions to those with semiarid conditions. In summary, a protected environment with a thick and mature forest that encourages soil preservation and litter development is the best environment for SOC preservation and formation.

Soil invertebrates depend on the energy obtained from the microbial degradation of organic matter, carrying out a positive feedback on such function and on the nutrient recycling processes (Potapov et al., 2017; Lajtha et al., 2018). Therefore, they are key players in several supporting and regulating ecosystem services (Lavelle et al., 2006). An extensive overview of the soil biodiversity is available in Coleman and Wall (2015) and in Orgiazzi et al. (2016), while Menta and Remelli (2020) focus on soil arthropods. In a nutshell (for further information see Wardle 2002), organic matter forming litter represents the basis of detritus-based food web whose primary consumers are bacteria and fungi (which respectively feed the so called "bacterial and fungal energy channels”). Enchytraeids (both microbial feeders and saprovores) and secondary consumers such as nematodes, oribatid mites, springtails, proturans are the most abundant organisms of the soil fauna; at the higher trophic levels are placed arachnids like predaceous mites, pseudscorpions, small spiders and centipedes. Total densities of animals, in moist soils rich in organic matter, can be of some hundreds of thousands of individuals/m² (Coleman and Wall, 2015; Orgiazzi et al., 2016).

Soil fauna is often used to provide soil quality indicators (Cortet et al., 1999; van Straalen, 2004; Parisi et al., 2005; Tabaglio et al., 2009; Menta et al., 2011; Cluzeau et al., 2012; Arredondo-Ruiz et al., 2013; Visioli et al., 2013; Menta and Remelli, 2020). Several authors have proposed methods for soil quality assessment through the analysis of soil fauna: some of them have a more general approach (Parisi et al., 2005), for others the evaluation of specific abundance and/or species richness of single faunal groups is required (Paoletti, 1999; Paoletti and Hassall, 1999; Parisi and Menta, 2008; Elo and Sorvari, 2019).

Since its introduction and improvement, the QBS-ar (Biological Quality of Soil, based on arthropods) index (Parisi, 2001; Parisi et al., 2005) has been applied in Europe, especially in the Mediterranean area, more rarely in Asia, both in studies aimed to assess soil quality in agroecosystems and in polluted or degraded sites, and to evaluate the impact of different disturbances in natural and semi-natural habitats (Aspetti et al., 2010; Blasi et al., 2013; Galli et al., 2014, 2015; Menta et al., 2018; Galli, 2020; Gonçalves et al., 2020). In general, based on what has been observed in Europe, in broadleaf deciduous forests typical of a temperate climate (Blasi et al., 2013) QBS-ar values remain comparable all over the year, whereas in Mediterranean sclerophyllous woods and bush, QBS-ar values vary monthly (Galli et al., 2014).

In Italy, this index is among those recommended by the national Agency for Environment Protection and Technical Services (APAT) and by the Institute for Environmental Protection and Research (ISPRA) for soil biomonitoring (Menta et al., 2018).
As far as we know, the QBS-ar index has never been used in the Southern Hemisphere yet.

The recent widespread use of the QBS-ar index is due both to its low cost and to the ease of execution: field soil cores collection is expeditious and laboratory analyses require generic taxonomic skills. Therefore, we decided to test this method for the first time in South America, by comparing four different habitats in the Chilean Natural Reserve of Coyhaique.

With this study we aimed to answer the following questions:

1) What is the abundance and diversity of soil microarthropods in different South American habitats?

2) Is the QBS-ar an index applicable in biogeographic regions other than the Palearctic and Oriental?

3) Does this index based on soil microarthropods enable to distinguish between habitats subject to different levels and types of disturbance also in the Neotropical region?

4) To what extent chemical parameters and weather conditions do affect microarthropods? Do their populations undergo seasonal fluctuations?

\section{Material and methods}

\subsection{Study area}

The study area is located in the Coyhaique National Reserve (Chilean Patagonia, XI Region: 45³0'40"S 7159'45"W) (Fig. 1).

Four sampling sites were chosen in the area of the Reserve, each of them showing different vegetation and soil conditions (CONAF, 2011):

1. primary native forest (OG - Coordinates 18GUTM: 0730818, 4954177; 733 m elev.)

2. native forest of secondary growth after fires (SG - Coordinates 18GUTM: 0731402, 4954166; $718 \mathrm{~m}$ elev.)

3. reforestation pine forest (PI - Coordinates 18GUTM: 0731178, 4953464; 674 m elev.)

4. anthropogenic grassland (PR - Coordinates 18GUTM: 0730332, 4951877; $436 \mathrm{~m}$ elev.).

The primary growth native forest is the most relevant vegetation in the reserve, both for extension and natural value. This deciduous Magellanic forest is dominated by Nothofagus pumilio (Poepp. \& Endl.), with Nothofagus dombeyi (Mirb.) and Nothofagus antarctica (G. Forst.) in lesser proportions. In the area other species are represented: Embothrium coccineum Forst., Berberis dentatoserrata (Heuf.), Myoschilos oblonga Ruiz \& Pav., Lycopodium paniculatum Desv. Ex Poir. and, among the herbaceous plants, Osmorhiza chilensis Hook. \& Arn. and Adenocaulon chilense Less. (CONAF, 2009). This forest extends on the slopes of Mount Cinchao, starting from 650-700 m elev. and represents one of the few examples of Chilean deciduous Magellanic forest not affected by the fires which went through the region during the first part of the 20th century.

The secondary growth native forest is characterized by the dominance of $N$. pumilio and $N$. dombeyi accompanied in lesser proportions by $E$. coccineum, B. dentatoserrata, M. oblonga, $L$. paniculatum, $O$. chilensis and $A$. chilense. This is a controlled 


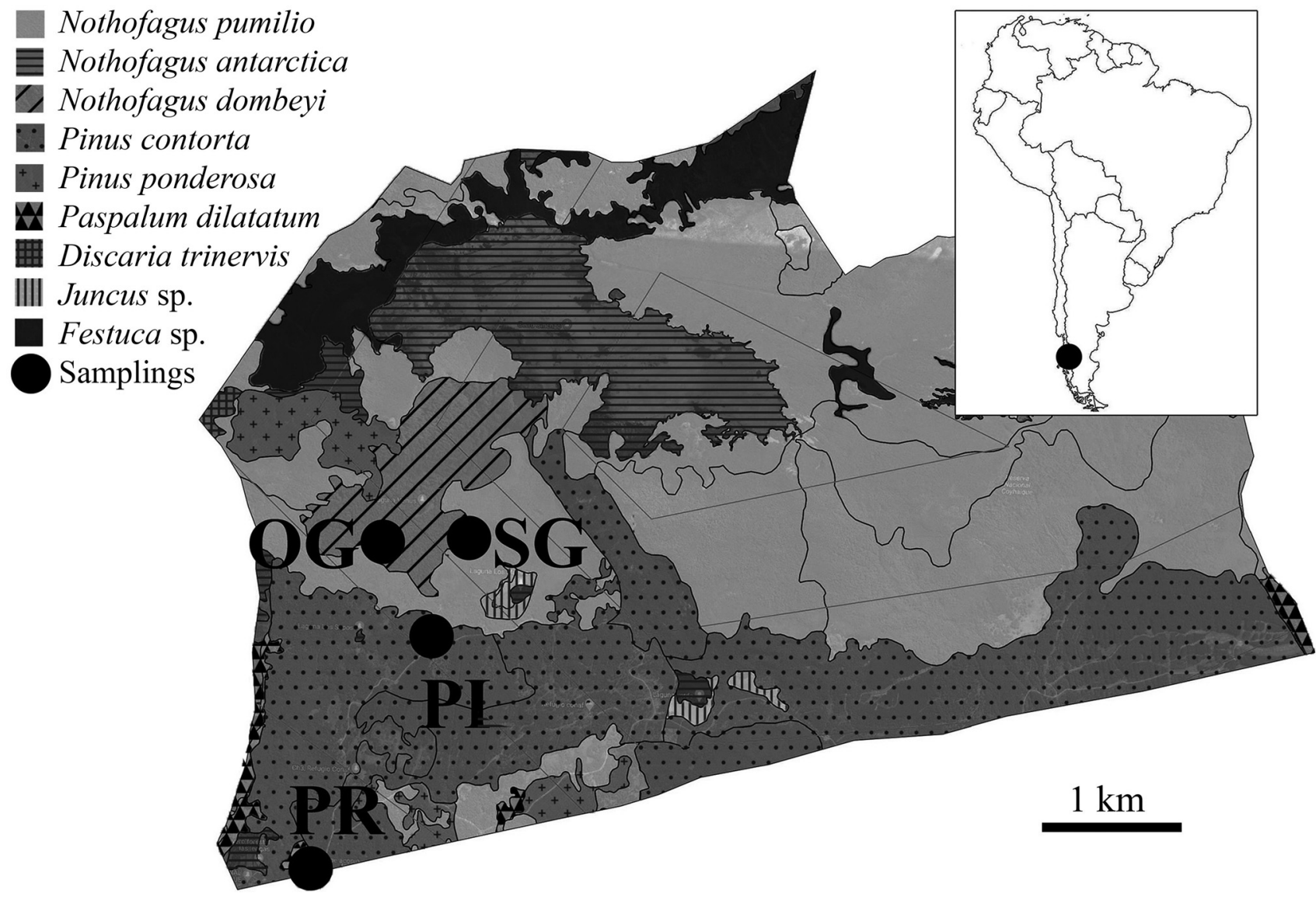

Fig. 1. Coyhaique Natural Reserve (Chile) map (from CONAF, 2011). OG = Primary native forest; SG = Native forest of secondary growth after fires; PI = Reforestation pine forest; PR = Anthropized grassland

growth Magellanic forest extending mainly on the south-west facing slope of Mount Cinchao, which was affected by fires during the first half of the 20th century.

The mixed forest of conifers, resulting from reforestation activities carried out since 1959 (CONAF, 2009), occupies an area of about 720 hectares and it's mainly present in the Reserve below $700 \mathrm{~m}$ elev. It is now composed by a variety of species, resulting from different reforestation interventions. Pinus sylvestris L., Pinus ponderosa Laws., Pinus contorta Doug., Pseudotsuga menziesii (Mirb.), Picea abies (L.) and Larix decidua Mill. are the most representative, but some deciduous species such as Betula pendula Roth and Alnus glutinosa (L.) can also be found. The shrub layer consists of: Berberis buxifolia Lam., Berberis darwini Hook., Ribes magellanicum Poir., Maytenus disticha (Hook F.), Escallonia virgate Mutis ex L.f., Fuchsia magellanica Lam., Baccharis sp., Pernettya mucronata (L.f.) Hook. and Arn. and Chusquea coleu Desv. Embothrium coccineum Forst. can also be found as colonizing species.

The grassland chosen for the study is located in the lower area of the reserve; it is used as building area and also as grazing area for horses and other animals in the Reserve. The vegetation is dominated by Poaceae, with a modest presence of Trifolium spp. and Acaena spp. and some shrubs such as Senecio spp., Ribes spp. and Berberis spp. (CONAF, 2009).
According to the WRB (IUSS Working Group WRB, 2014), soils occurring in this landscape are primarily vitric or umbric Andosol developed in volcanic ejecta or on lava flows from active volcanoes in the region (Gardi et al., 2105). These soils usually exhibit high levels of organic matter due to accumulation of stable organo-mineral complexes and strong phosphate fixation.

Weather conditions of the area are available online (website 1) by selecting station 450004 (Teniente Vidal, Coyhaique). In order to highlight any possible influence on soil arthropods, data of cumulated rainfalls and mean daily temperatures during the seven days preceding each sampling session were taken into consideration (Table 1).

\subsection{Field and laboratory methods}

At each sampling site, a representative central area was delimited, homogeneous in terms of slope and vegetation. Five 10 $\mathrm{x} 10 \times 10 \mathrm{~cm}$ soil cores were collected after removing the above ground plant cover and surface litter, at the corners and at the intersection of the diagonals of a square with seven meter sides.

Samples were collected always within the same four core areas during October 13 and 23, November 2, 14 and 24, December 6 and 18 (2017), January 15 (2018) in order to check if there were any monthly fluctuations in the soil arthropods abundance. On 
Table 1

Weather conditions in Coyhaique Natural Reserve during the field activities: cumulated rainfalls and mean daily temperatures during the seven days preceding each sampling session

\begin{tabular}{lll}
\hline Date & Cumulated Rainfalls $(\mathrm{mm})$ & Mean T $\left({ }^{\circ} \mathrm{C}\right)$ \\
\hline 13.10 & 21.8 & 6.5 \\
23.10 & 13.7 & 7.3 \\
02.11 & 3.2 & 9.2 \\
14.11 & 14.9 & 11 \\
24.11 & 0 & 9 \\
06.12 & 0 & 14.5 \\
18.12 & 29.9 & 13.2 \\
\hline
\end{tabular}

the same day of collection they were carried to the laboratory of the Centro de Investigación en Ecosistemas de la Patagonia (CIEP) in Coyhaique for the extraction. Extractions of grassland samples (PR) taken on the last sampling session, $15^{\text {th }}$ January 2018, inexplicably failed, resulting almost null. Therefore, for homogeneity, data about this date were excluded from any elaboration and analysis, except one (see section 2.3 Statistical analyses).

Microarthropods were extracted into vials containing $70 \%$ Ethanol using Berlese-Tullgren funnels ( $2.5 \mathrm{~mm}$ mesh size) for 710 days (Bano and Roy, 2016). The content of each vial was then analysed using a 20x/40x stereomicroscope in order to identify specimens at the order or class (only myriapods and apterygote hexapods) levels.

Specimens belonging to each taxon were counted in order to get a quantitative data set on the microarthropod communities integrating the qualitative QBS-ar approach (see below).

The QBS-ar index (Parisi et al., 2005; Tabaglio et al., 2009; Menta et al., 2011) is based on the positive correlation between the number of microarthropod groups which are well adapted to soil habitats and the soil quality. Each group of soil arthropods present in a sample is evaluated according to morphological characteristics that give evidence of adaptation to soil environment, such as reduction or loss of pigmentation and visual apparatus; tiny and/or streamlined body form, with reduced and transformed appendages (hairs, antennae, legs); reduction or loss of flying, jumping or running adaptations; the presence of peculiar sense organs. Based on these characteristics, an ecomorphological index (EMI) ranging from 1 (no adaptation to soil) to 20 (in the euedaphic forms: full adaptation), is given to each taxon (order or class). Some orders/classes that are strictly euedaphic (Acarina, Palpigrada, Pseudoscorpionida, Symphyla, Pauropoda, Protura and Diplura), hemiedaphic (Opilionida, Isopoda, Microcoryphia, Zygentoma, Embioptera, and larvae of holometabolous insects) and not-edaphic (Dermaptera, Psocoptera, Thysanoptera, Diptera) have fixed EMI values: 20, 10 and 1, respectively. Eco-morphological values of the other taxa need to be assessed according to easy keys, based on the highest degree of adaptation to soil recorded among extracted specimens. The QBS-ar value results from the sum of the EMI scores of all the arthropod groups extracted. Such value, the number of euedaphic taxa and the presence/absence of specific groups (Colle- mbola Onychiuridae, Protura and euedaphic Coleoptera) allow to assign the soil to one of eight different quality classes (from 0 to 7). For a more detailed description of the method, see the literature cited above. In this study, QBS-ar values were calculated for each habitat considering the 5 soil cores of a single sampling session as representative subsamples of different microhabitats. Therefore, the results of microarthropods' extraction from the five subsamples collected on a date were cumulated in order to obtain a larger pool of organisms, from potentially different soil environments, based on which the index was computed.

In order to characterize the chemical properties of the soils, at each of these sampling sites two $15 \mathrm{~cm}$ deep soil cores were removed via auguring from A horizon and mixed together to obtain a single $1 \mathrm{~kg}$ soil sample/habitat. Before collecting each core, we removed all recognizable litter from the soil surface (Oi horizon). After collection, each core was placed in a labelled bag that was immediately sealed and maintained in a cooler in fresh conditions $\left(<15^{\circ} \mathrm{C}\right.$ air temperature) for ca. $2 \mathrm{~h}$ to minimize nutrient mineralization, then they were placed in a refrigerator $\left(3^{\circ} \mathrm{C}\right)$ for two days and shipped to a soil testing laboratory (Regional Soil Analysis Laboratory in Sarzana, Italy, ISO 9001 certified). For each soil sample, the following routine laboratory procedures and analyses were performed according to the Ministero delle Politiche Agricole e Forestali (Mipaf, 2000): $\mathrm{pH}$ was measured by potentiometry in a 1:2.5 soil:water suspension. Total carbonate content was determined using the Dietrich Früling calcimeter. Total Organic Carbon (TOC) and N content were determined using an elemental analyser (Velp CN 802) by means of high-temperature $\left(1000^{\circ} \mathrm{C}\right)$ combustion (Dumas, 1831) and removing inorganic carbon (carbonates) in the sample by pre-treatment (Kerven et al., 2000). Measurements of organic carbon can be used to estimate organic matter (OM) through the use of a conversion factor, which assumes that $58 \%$ of the OM was formed by carbon (Nelson and Sommers, 1996). The cation exchange capacity (CEC) and exchangeable bases were determined with $\mathrm{BaCl}_{2}$-triethanolamine at a $\mathrm{pH}$ of 8.2 ; soluble $\mathrm{P}$ was determined using $\mathrm{NaHCO}_{3}$ (Olsen et al., 1954).

\subsection{Statistical analyses}

Software PAST (version 4.02) (Hammer et al., 2001) was used to perform the following statistical analyses.

Chemical parameters of soils (Table 1) were used to assess the "abiotic similarity" among the four sampling sites, by means of Ward's method Clustering (1000 bootstraps). The same method was used to assess "biotic similarity" among habitats, based on the total number of microarthropods belonging to each taxon extracted during the seven examined sampling sessions.

Based on quantitative data (summing the five sub-samples), the community composition and diversity were estimated, calculating the Shannon diversity $(\mathrm{H})$ and the Simpson dominance (D) indices.

In order to assess differences among microarthropod communities of the four habitats, quantitative data of each sample were ordinated by Non metric multidimensional scaling, adopting Bray-Curtis distance index. On the same dataset the One-way ANOSIM (9999 permutations) was performed, based on Bray- 
Curtis similarity index and applying Bonferroni correction. The contribution of each taxon to the recorded differences was estimated through SIMPER analysis.

The same kind of data processing was carried out with the aim of highlighting any significant variation of communities during the research. Data from all four habitats were grouped by sampling date from October to December 2017 and analyzed by means of One-way ANOSIM. In order to examine a wider time frame, One-way ANOSIM was performed also on data from three habitats (excluding PR) along the whole sampling period from $13^{\text {th }}$ October 2017 to $15^{\text {th }}$ January 2018.

The sensitivity of QBS-ar index and Quality Classes was tested performing One-way ANOVA on values calculated for all collected samples and examining the output of Tukey's pairwise comparisons among the four habitats.

The relationships among different soil microarthropod classes and soil chemical parameters (see Table 1) on one side and weather conditions on the other were investigated by a canonical correspondence analysis. In the former case, only data about dominant/subdominant eu- and hemi-edaphic taxa were used, assuming they were the most sensitive to soil characteristics. In the latter case, general data about the most frequent orders were plotted in relation to cumulated rainfalls and mean temperatures in the seven days preceding the sampling.

\section{Results}

\subsection{Soil properties}

The chemical analyses (Table 2) documented overall that these soils are rich in organic matter, reflecting the greater organic carbon inputs associated with a more mature and betterestablished vegetation community in forest types (OG, SG, PI). An exception was represented by PR where we registered a decrease of organic matter due to human impact interference with soil formation processes through vegetation changes caused by deforestation. Generally, the $\mathrm{C} / \mathrm{N}$ ratio of these last soils (PR) is near 10, indicating a Mull humus form, characterized by wellhumified organic matter with stable mineral-organic complexes whereas in forested environments (OG, SG, PI) the acidic pH of the organic horizons induces a decrease in litter decomposition rates and is reinforced by slow humification $(\mathrm{C} / \mathrm{N}$ ratios of approximately 20) with formation of the Moder humus form. In fact, soil reaction was generally slightly acid, with the highest $\mathrm{pH}\left(\mathrm{H}_{2} \mathrm{O}\right)$ value, which was 6.7, recorded in PR. The CEC values significantly increase in the forest soils and appear to be directly correlated to the organic matter content.

The majority of the soils completely leached of carbonates (this may explain their low $\mathrm{pH}$ ) but it should be noted that soils in the $\mathrm{PR}$ are characterized by higher $\mathrm{CaCO}_{3}$ content likely due to the preparation and management of plots before, during and after the production phase (probably due to calcination remediation interventions). P in PR showed low value, but high values occurred in forest sites. Moreover, the soils in these sites have high $\mathrm{N}$ contents while lower values occurred in PR which, however, has high $\mathrm{K}$ values that could be linked to the addition of fertilizers.

\subsection{Soil micro-arthropods}

From the 155 soil cores collected, a total of 21,491 microarthopods were extracted. In Appendix 1 such results are summarized, cumulating for each sampling session the data obtained from the five sub-samples collected per habitat. For completeness of information, also data of January 2018 (from PI, SG and OG) are reported, even though omitted in most of the analyses.

Non metric multidimensional scaling with Bray-Curtis similarity index based on the whole dataset, excluding January 2018 (see Field and laboratory methods), does not show a clear distinction among habitats (Fig. 2), while the One-way ANOSIM highlights highly significant differences among them $(\mathrm{R}=0.06831$; $\mathrm{p}($ same $)=0.0001)$. Pairwise differences (Bonferroni correction applied) are shown in table 3. Pine forest (PI) results significantly different from grassland (PR) and secondary growth forest (SG); $\mathrm{PR}$ is also significantly different from primary native forest (OG), and its difference from secondary growth forest (SG) is close to statistical significance. Microarthropod communities of OG and SG result statistically indistinguishable. Overall distances among habitats' communities are shown in Fig. 3. Two clusters emerge with rather good bootstrap support: PI-PR on one side, and SG-OG on the other. This result is partly consistent with the distances among the soils of such habitats evidenced by Ward's clustering based on chemical properties shown in table 1 (Fig. 4).

SIMPER analysis evidenced an overall average dissimilarity of $65.13 \%$, with mites and springtails totally contributing in every pairwise comparison to at least the $70 \%$ of the differences between habitats evidenced by One-way ANOSIM.

Table 2

Soil chemical parameters in the sampling sites. OG = Primary native forest; SG = Native forest of secondary growth after fires; PI = Reforestation pine forest; PR = Anthropogenic grassland

\begin{tabular}{|c|c|c|c|c|c|c|c|c|}
\hline & $\begin{array}{l}\mathrm{pH} \\
\left(\mathrm{H}_{2} \mathrm{O}\right)\end{array}$ & $\begin{array}{l}\text { C.E.C. }{ }^{a} \\
(\mathrm{meq} / 100 \mathrm{~g})\end{array}$ & $\begin{array}{l}\mathrm{CaCO}_{3} \\
(\%)\end{array}$ & $\begin{array}{l}\mathrm{N} \\
(\mathrm{g} / \mathrm{kg})\end{array}$ & $\begin{array}{l}\mathrm{P}^{\mathrm{b}} \\
(\mathrm{mg} / \mathrm{kg})\end{array}$ & $\begin{array}{l}\mathrm{K}^{\mathrm{b}} \\
(\mathrm{mg} / \mathrm{kg})\end{array}$ & $\begin{array}{l}\text { O.M. }{ }^{c} \\
(\%)\end{array}$ & $\mathrm{C} / \mathrm{N}$ \\
\hline PR & 6.7 & 13.8 & 1.76 & 1.82 & 6 & 297.2 & 4 & 12.6 \\
\hline PI & 5.9 & 36.2 & 0 & 6.8 & 122 & 215.1 & 16.6 & 14.2 \\
\hline SG & 6.4 & 28.9 & 0 & 4.6 & 32 & 152.5 & 15.7 & 19.9 \\
\hline OG & 6.1 & 30.8 & 0 & 7.5 & 40 & 226.8 & 20.2 & 15.7 \\
\hline
\end{tabular}

${ }^{\mathrm{a}}$ C.E.C.: cation exchange capacity; ${ }^{\mathrm{b}}$ exchangeable; ${ }^{\mathrm{c}}$ O.M.: organic matter. 


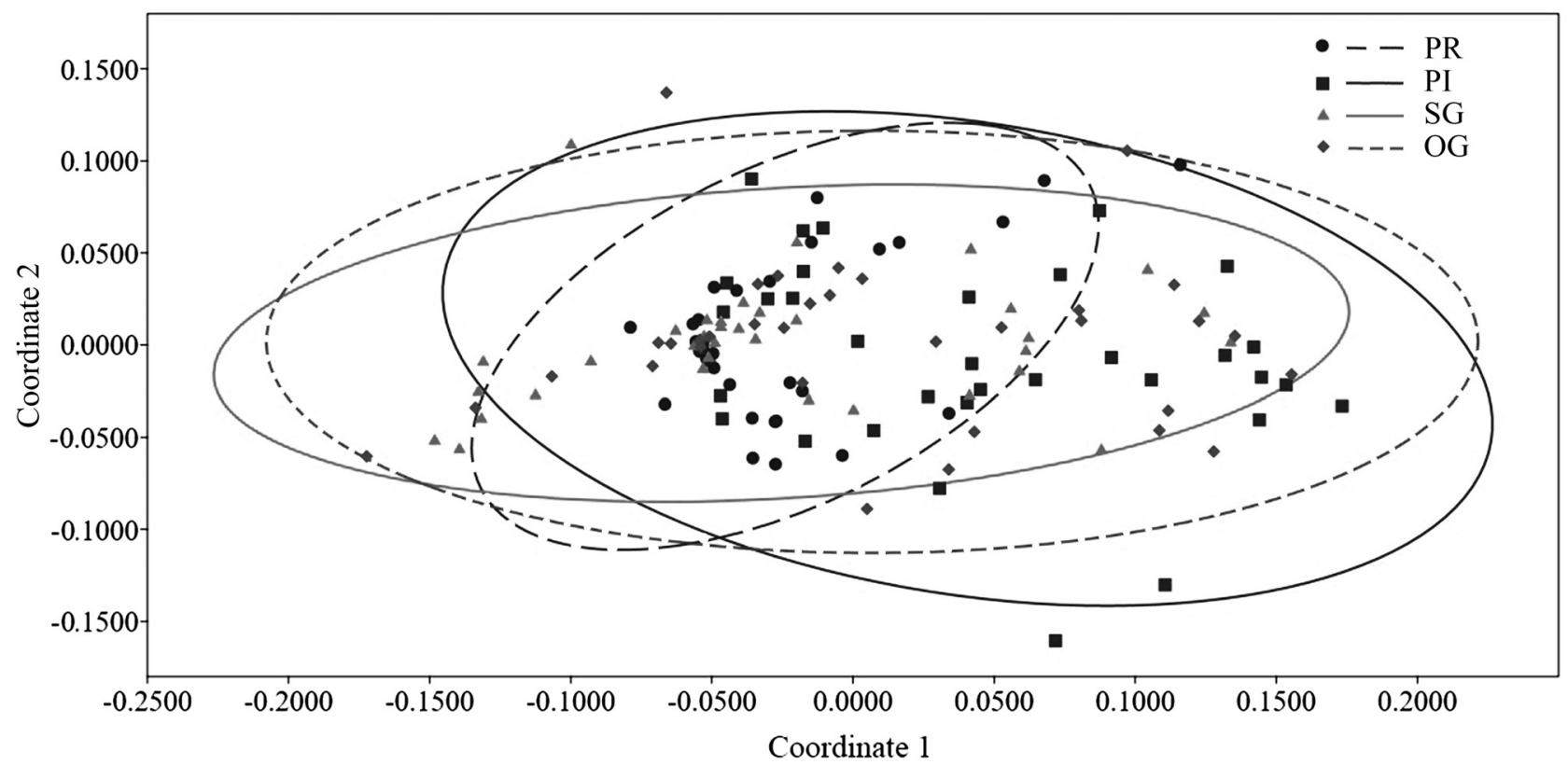

Fig. 2. Non metric multidimensional scaling based on the whole extracted microarthropods dataset; $95 \%$ ellipsis are drawn

Table 3

One-way ANOSIM (Bray-Curtis distance index, Bonferroni corrected $\mathrm{p}$ values) pairwise comparisons between habitats. Highly significant differences are highlighted in light grey, those in dark grey are close to statistical significance

\begin{tabular}{lllll}
\hline & PR & PI & SG & OG \\
\hline PR & & 0.0006 & 0.072 & 0.0012 \\
PI & 0.0006 & & 0.0204 & 0.1674 \\
SG & 0.072 & 0.0204 & & 1 \\
OG & 0.0012 & 0.1674 & 1 & \\
\hline
\end{tabular}

The Shannon diversity (H) and the Simpson dominance (D) indices were calculated to assess the biodiversity at the order level for each habitat. Their variation among the seven sampling sessions from October to December 2017 is shown in Fig. 5. The most homogeneous community with the highest diversity is the primary Nothofagus forest (OG); on the contrary, the secondary growth forest, with the highest recorded number of arthropods, results the less diverse habitat, due to a high dominance level. Pine forest community, even though characterized by the lowest number of individuals, has an intermediate diversity level due to its low dominance value. Finally, grassland shows intermediate values both in terms of microarthropods' density and their diversity.
Fig. 3. Clustering based on microarthropod community composition in the four habitats (Ward's method, 1000 bootstraps - Cophenetic correlation 0.6977). Bootstraps values are reported under the nodes

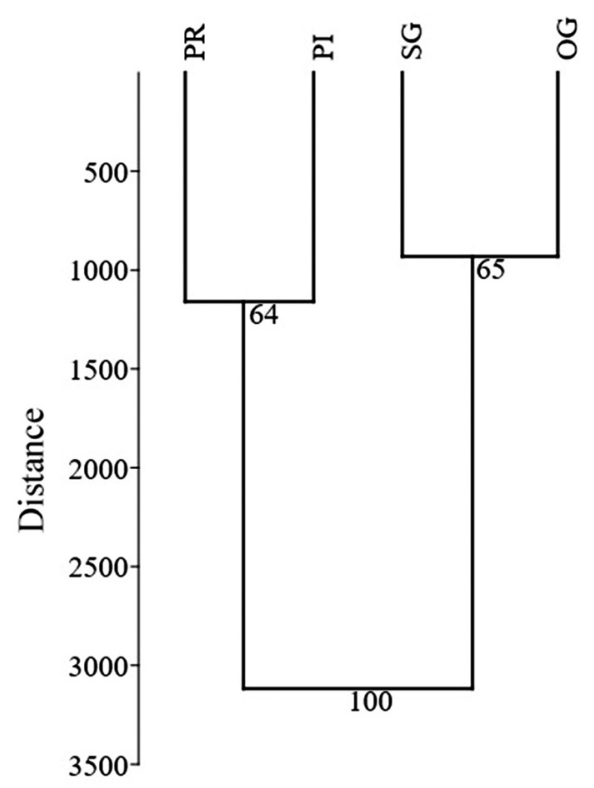

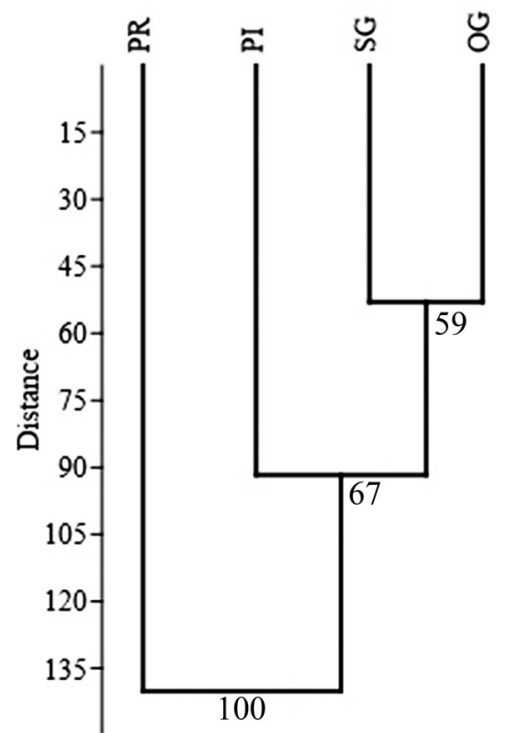

Fig. 4. Clustering based on chemical properties of soils (Ward's method, 1000 bootstraps - Cophenetic correlation 0.6572 ). Bootstraps values are reported under the nodes 
Fig. 5. Box-plots of Shannon diversity (H) and Simpson dominance (D) indices values calculated for each sampling session in the four studied habitats

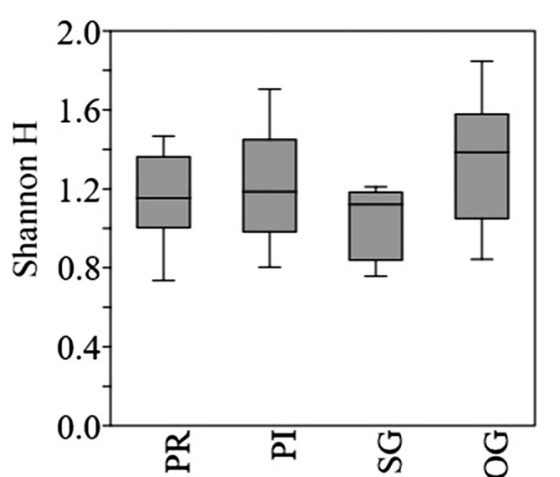

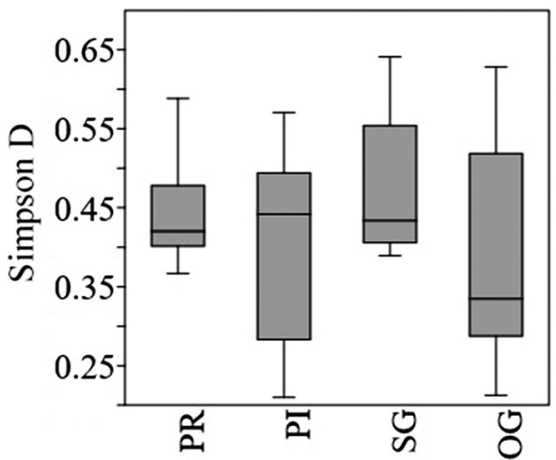

The relationships among dominant and subdominant soil arthropods and chemical parameters of soils on one side and weather conditions on the other can be cautiously outlined based on the canonical correspondence analysis outputs shown in figures 6 and 7, respectively. In general, eu- and hemi-edaphic taxa (Acarina, Chilopoda Geophilomorpha, euedaphic Collembola, Protura, hemi- and euedaphic Coleoptera) appear to be positively influenced by $\mathrm{C} / \mathrm{N}$ ratio, organic matter, $\mathrm{N}$ and cationic exchange capacity. Less relevant seems to be the influence of $\mathrm{pH}$, negative on Chilopoda Geophilomorpha and positive on Coleoptera. $\mathrm{CaCO}_{3}$, $\mathrm{P}$ and $\mathrm{K}$ would influence more or less negatively all the taxa mentioned above; just hemi-edaphic Collembola would be positively related to such factors. The output based on weather conditions is bipartite. Mean temperature vector lies on
Fig. 6. Canonical correspondence analysis among eu- and hemi-edaphic taxa and chemical characteristics of soils (See also table 1). Axis 1 explains $93.56 \%$ of variance, axis 2 the $3.937 \%$

Fig. 7. Canonical correspondence analysis among dominant and subdominant taxa and weather conditions (mean temperatures and cumulated rainfalls during the seven days before each sampling session). Axis 1 explains $99.94 \%$ of variance
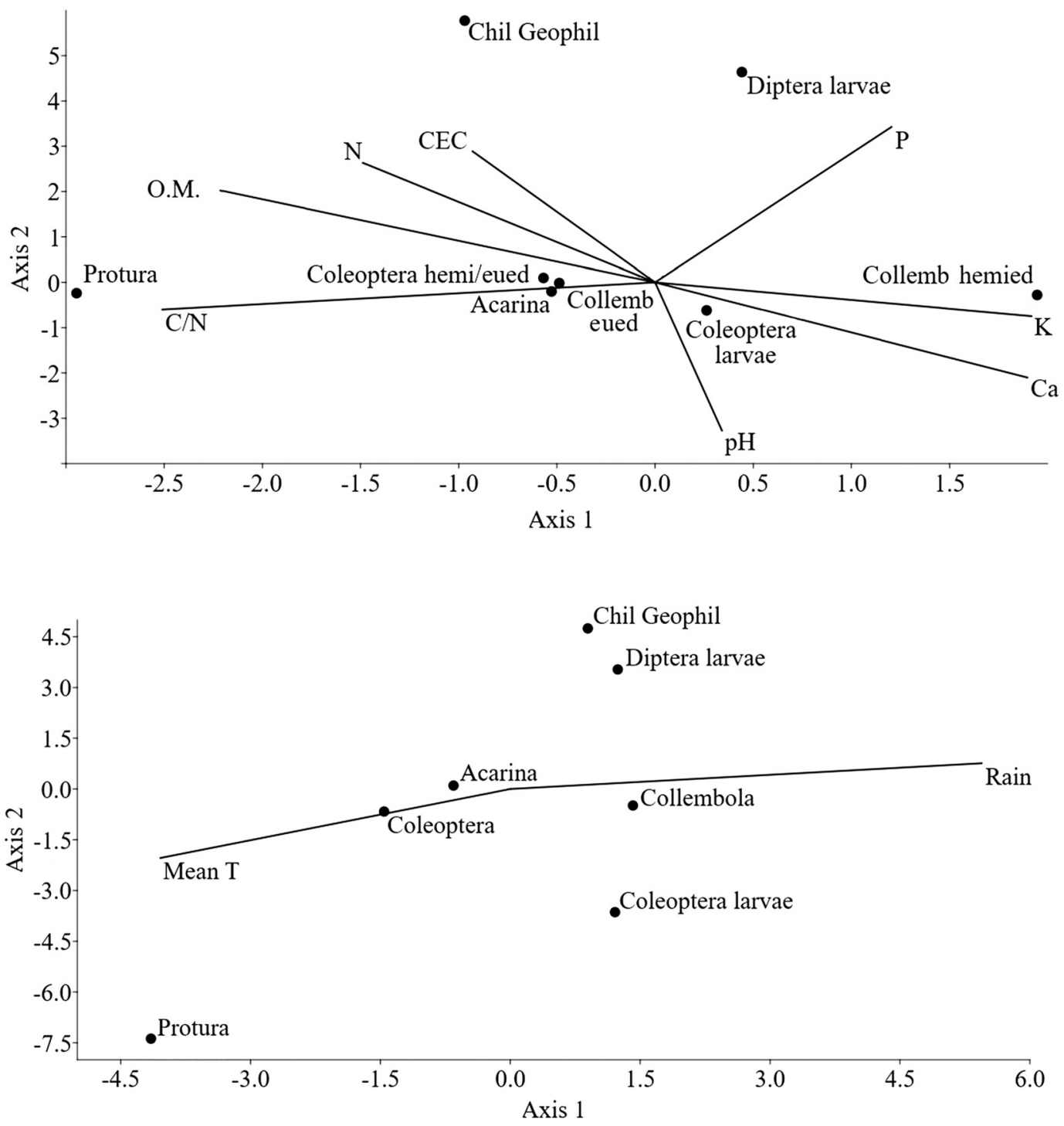
the negative side of axis 1 with Acarina, Protura and Coleoptera; on the positive side lie rainfalls vector with Chilopoda Geophilomorpha, Collembola and larvae of both Coleoptera and Diptera. Nevertheless, at least partly due to the low number of samplings, linear regression models applied to the examined taxa and environmental variables result generally not significant, or statistically significant but supported by very low $\mathrm{R}^{2}$ values.

One-way ANOSIM performed on data of microarthropod communities grouped according to sampling date showed no significant difference for either all four habitats during the last three months of 2017 or for PI-SG-OG during the whole period ending on $15^{\text {th }}$ January 2018 . These results indicate that in each habitat the microarthropod community remained unchanged at least over the three months monitored. This seems to indicate a lack of significant seasonal fluctuations in the populations investigated.

\subsection{Biological quality of soils}

The QBS-ar indices and the related quality classes were calculated for each habitat and collecting date. Their variation among the seven sampling sessions from October to December 2017 is shown in Fig. 8.

It is evident that the biological quality of soil index' result reflects what has been highlighted on the basis of the analysis of the microarthropod communities illustrated in Fig. 3. PI and PR are close to each other and the same is true for SG and OG. In particular, soils of this latter couple of habitats are characterized by a higher biological quality.

The Tukey's pairwise comparisons between habitats obtained performing One-way ANOVA on QBS-ar values and quality classes during the seven sampling sessions are shown in Table 4. In both cases PR and PI result significantly different from SG and OG, corroborating the consideration made above based on mean values.

\section{Discussion}

In our study, only four habitats were analyzed, and among them only the primary native forest can be considered a natural habitat. Based on the analysis of their soil arthropods, pine for-
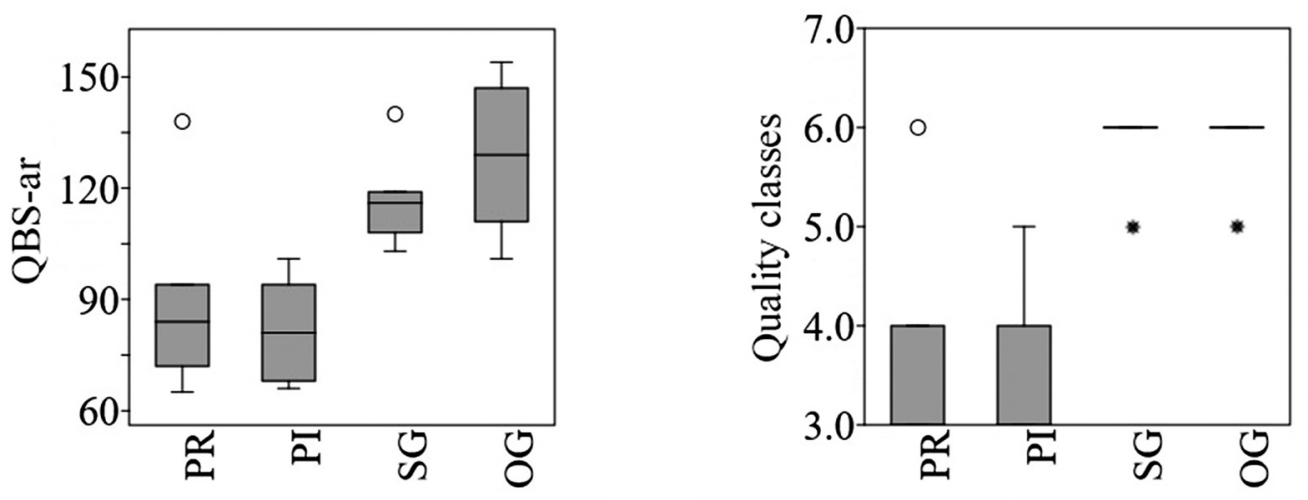

Fig. 8. Box-plots of QBS-ar index and quality classes values calculated for each sampling session in the four studied habitats. Open circles and stars represent maximum and minimum outliers, respectively

Table 4

One-way ANOVA on QBS-ar values and related quality classes. Tukey’s pairwise comparisons between habitats. $Q$ values are below diagonal, $\mathrm{p}($ same) above diagonal. Significant differences are highlighted

\begin{tabular}{lllll}
\hline QBS-ar & PR & PI & SG & OG \\
\hline PR & & 0.9384 & 0.04382 & 0.001719 \\
PI & 0.8144 & & 0.0119 & 0.000409 \\
SG & 3.988 & 4.803 & & 0.5275 \\
OG & 5.93 & 6.745 & 1.942 & \\
\hline
\end{tabular}

\begin{tabular}{lllll}
\hline Quality classes & PR & PI & SG & OG \\
\hline PR & 1 & 0.00003313 & 0.00003313 \\
PI & 0 & & 0.00003313 & 0.00003313 \\
SG & 8.172 & 8.172 & & 1 \\
OG & 8.172 & 8.172 & 0 & \\
\hline
\end{tabular}


est resulted significantly different from grassland and secondary growth forest; grassland was also significantly different from primary native forest, and its difference from secondary growth forest was close to statistical significance. Two clusters emerged based on overall distances among habitats' communities: pine forest-grassland on one side, and primary-secondary growth native forests on the other. These results were confirmed by values of biological quality of soil based on microarthropods (QBS-ar) index: pine forest and grassland were close to each other and the same was true for secondary and primary native forests. In particular, soils of this latter couple of habitats were characterized by a higher biological quality. Based on Shannon diversity (H) and the Simpson dominance (D) indices, the primary Nothofagus forest was the most "homogeneous" community with the highest diversity. The secondary growth forest, with the highest recorded number of arthropods, resulted the less diverse habitat, due to a high dominance level. Pine forest community, even though characterized by the lowest number of individuals, had an intermediate diversity level due to its low dominance value. Finally, grassland showed intermediate values both in terms of microarthropods' density and their diversity. Starting from this last habitat, values of QBS-ar index $(80.3 \pm 10.8)$ and Shannon diversity $(1.15 \pm 0.24)$ are close or even higher than those recorded in some agricultural and pastoral environments (Tabaglio et al., 2009; Mazzoncini et al., 2010; Zucca et al., 2010; Menta et al., 2011; Sapkota et al., 2012) or in some urban or degraded ecosystems (Hartley et al., 2008; Madej et al., 2011; Santorufo et al., 2012). On the contrary, in other terrestrial ecosystems subject to different forms of management and anthropic impact quality scores higher that that obtained in the studied grassland were recorded (Hartley et al., 2008; Tabaglio et al., 2009; Andrés et al., 2011; Madej et al., 2011; Menta et al., 2011; Santorufo et al., 2012; Sapkota et al., 2012). The Pine forest QBS-ar value we obtained (83 \pm 13.5$)$ is inferior to values recorded under umbrella pines in Italy (Blasi et al., 2013). Also the quality index values obtained for the broadleaf forests monitored (both secondary growth and primary native ones) were generally lower (even much lower) than those known in literature for various European forests, that sometimes reach or pass 200, with corresponding Shannon diversity values even passing 1.5 (Menta et al., 2011; Blasi et al., 2013; Galli et al., 2014). In order to explain such differences, it would be necessary an extension of the research presented in this paper in the same area to other months, but also in different areas characterized by other habitats.

About the relationships among soil arthropods and chemical parameters, it can be said that generally speaking a positive influence of organic matter supply on the soil fauna is more than obvious. Moreover, the $\mathrm{C} / \mathrm{N}$ ratio can be considered an index of the quality and ease of biodegradation of such organic matter (Kotroczó et al., 2020). In soils with higher $\mathrm{C} / \mathrm{N}$ ratio the fungal contribution to biodegradation tend to prevail and this has a positive effect on microarthropods communities, starting from the secondary mycophagous consumers (Wardle, 2002). Deepening the analysis, however, the influences of different soil characteristics on arthropods (and on the soil fauna in general) resulting from studies published in literature are often unclear, if not contradictory. For example, Hasegawa (2002) and Salmon et al. (2008) showed that Shannon diversity index can be linearly correlated to soil $\mathrm{pH}$, humus forms, and levels of organic carbon. Soil $\mathrm{pH}$ resulted to have a significant direct positive effect on the soil fauna richness (Moço et al., 2010) and densities and local diversity of Collembola were observed to increase with soil acidity (Loranger et al., 2001). A negative correlation of $\mathrm{pH}$ with springtails richness, was recorded also by da Silva et al. (2016), who identified it as the main soil parameter influencing Collembola communities descriptors. In a study on grassy arable fallows, oribatid mite assemblages resulted to be influenced in their species composition by $\mathrm{pH}$ as well as by organic carbon, microbial carbon and water content (Wissuwa et al., 2013). Furthermore, an indirect influence of $\mathrm{pH}$ on oribatid mites density through humus form was outlined by Maraun and Scheu (2000). A negative effect of $\mathrm{pH}$ was recorded on Protura density in Italian chestnut and beech forests (Galli et al., 2019). On the contrary, in New Zealand forests, no relationship between soil organic matter, nitrogen, phosphorus, $\mathrm{pH}$, cation exchange capacity, and the density of Protura was found (Minor, 2008). An absence of direct correlation between abundance of soil microarthropods and soil chemistry was found also in Finnish peatlands drained for forestry (Laiho et al., 2001). In the forest habitats we examined, in particular, the level of phosphorus was high and this element resulted negatively related to euedaphic microarthropods. Young, volcanic soils of the southern Andes are known to have a high total P content (Borie and Rubio, 2003), but several studies using similar methodology have suggested $\mathrm{P}$ availability is low (Piper et al., 2013; Fajardo and Piper, 2015), because $\mathrm{PO}_{4}$ is readily precipitated by aluminum- and iron-complexes (Piper et al., 2013). The high $P$ availability we recorded in forest types may be due to their interference with these $\mathrm{PO}_{4}$ binding reactions, or enhanced weathering associated with their ectomycorrhizal fungi (Chen et al., 2008; Gundale et al., 2008).

In each of the habitats examined the microarthropod community remained unchanged over the period monitored providing a clue about the lack of significant seasonal fluctuations in the populations investigated. However, the three months period monitored is not long enough to evidence with absolute certainty any seasonal fluctuations of microarthropod communities. In Europe, in broadleaf deciduous forests typical of a temperate climate (Blasi et al., 2013) QBS-ar values remained comparable all over the year, whereas in Mediterranean sclerophyllous woods and bush, QBS-ar values varied monthly (Galli et al., 2014). An evident seasonal pattern can be reasonably hypothesized also for other environments where significant variations of microarthropod community abundance and diversity are known or expected: e.g. high mountain habitats (Wu et al., 2014). Moreover, after a research on grasslands, woodlands and arable lands of the Po valley (North Italy), no significant seasonal differences of the community indices examined such as Shannon diversity and Acarina/Collembola ratio were observed for any of the land use typologies. On the contrary, a significant seasonal difference of QBS-ar values was observed in arable lands (Menta et al., 2011). Therefore, in the sampling design of studies aimed at the evaluation of soil biological quality it is suggested to carefully take into account the aspect of faunal seasonality depending on local climate and habitat type (Galli et al., 2014). 
This aspect can be related also to the influence of weather conditions on soil fauna. According to our results mean temperature would be positively related to Acarina, Protura and Coleoptera; rainfalls to Chilopoda Geophilomorpha, Collembola, larvae of both Coleoptera and Diptera. Responses of soil arthropods to weather extremes like summer droughts vary depending on feeding strategies and life history (Staley et al., 2007). For example, in the Mediterranean and in other temperate areas Protura probably perform vertical migrations in soil depending on temperature and moisture levels even though some authors suggest that they could also enter into a state of torpor in response to adverse conditions (Galli et al., 2019). Many species of Collembola become dormant or quiescent in response to low relative humidity, some others survive the dry summer laying eggs which are resistant to desiccation (Hopkin, 1997); moreover, moisture stress conditions can cause a significant reduction of fecundity (Choi et al., 2006). An influence of temperatures on springtail species abundance and vertical distributions was recorded too (Rendoš et al., 2016).

\section{Conclusions}

1. The abundance and diversity of soil microarthropods in four habitats in the Coyhaique National Reserve (Chile) were assessed. The primary Nothofagus forest was the most "homogeneous" community with the highest diversity. In the native forest secondarily grown after fires arthropod assemblages reached the highest number of individuals, but the diversity was the lowest, due to a high dominance level. Reforestation pine forest community was characterized by the lowest number of individuals and an intermediate diversity level, due to a low dominance value. Finally, grassland showed intermediate values of microarthropods' density and diversity.

2. Our results seem to indicate that QBS-ar index can be "exported" to South America, resulting a useful tool for a user friendly assessment of the impact on terrestrial environments by different forms of disturbances and habitat management.

3. The quantitative analysis of the microarthropod communities and the QBS-ar values gave comparable results in differentiating the four habitats investigated. However, the advantage of using QBS-ar index appears evident. Its approach is based on the simple attribution of the highest EMI score to each taxon extracted from a soil sample, without the need to count the individuals.

4. The outcomes of the analysis of the relationships among dominant/subdominant microarthropods and some chemical properties of soils, on the one hand, and weather variables, on the other, deserve more in depth investigations on a larger pool of habitats. Moreover, the three months period monitored is not long enough to evidence with absolute certainty any seasonal fluctuations of microarthropod communities.

5. A more extensive application in a wider range of habitats and climates is needed in order to verify if some minor adjustments could be necessary, but our research highlighted the sensitivity and reliability of such method even in the Neotropical biogeographical region.

\section{Acknowledgements}

We thank Paulo Moreno and Luis Uribe (Centro de Investigación en Ecosistemas de la Patagonia) for the useful discussions during all the phases of our study. Many thanks also to Alex Fajardo (Centro de Investigación en Ecosistemas de la Patagonia) for his helpful assistance in data collection, to Giorgio Bavestrello (Università di Genova) and Giovanni Daneri (Centro de Investigación en Ecosistemas de la Patagonia) for their support and useful help in the organization of the research. Many thanks also to the anonymous reviewers whose suggestions helped us to improve our manuscript.

This research was partly supported by Centro de Investigación en Ecosistemas de la Patagonia (CIEP) and by CINDA Program of Genoa University.

\section{References}

Andrés, P., Mateos, E., Tarrasón, D., Cabrera, C., Figuerola, B., 2011. Effects of digested, composted, and thermally dried sewage sludge on soil microbiota and mesofauna. Applied Soil Ecology 48, 236-242. https://doi.org/10.1016/j.apsoil.2011.03.001

Arredondo-Ruiz, F., García-Montero, L.G., Menta, C., Valverde-Asenjo, I., Menta, C., 2013. Soil quality indicators for forest management. [In:] Martínez-Falero, E., Martín-Fernández, S., García-Abril, A. (Eds.), Quantitative techniques in participatory forest management. CRC Press, Taylor \& Francis, Boca-Ratón, 179-240.

Aspetti, G.P., Boccelli, R., Ampollini, D., Del Re, A.A.M., Capri, E., 2010. Assessment of soil-quality index based on microarthropods in corn cultivation in Northern Italy. Ecological Indicators 10(2), 129-135. https://doi.org/10.1016/j.ecolind.2009.03.012

Bano, R., Roy, S., 2016. Extraction of soil microarthropods: a low cost Berlese-Tullgren funnels extractor. International Journal of Fauna and Biological Studies 3(2), 14-17. https://www.faunajournal.com/archives/2016/vol3issue2/PartA/3-1-13.pdf

Blasi, S., Menta, C., Balducci, L., Conti, F.D., Petrini, E., Piovesan, G., 2013. Soil microarthropod communities from Mediterranean forest ecosystems in Central Italy under different disturbances. Environmental Monitoring and Assessment 187(2), 1637-1655. https://doi. org/10.1007/s10661-012-2657-2

Borie, F., Rubio, R., 2003. Total and organic phosphorus in Chilean volcanic soils. Gayana Botanica 60, 69-73. http://dx.doi.org/10.4067/S071766432003000100011

Breuning-Madsen, H., Elberling, B., Balstroem, T., Holst, M., Freudenberg, M., 2009. A comparison of soil organic carbon stock in ancient and modern land use systems in Denmark. European Journal of Soil Science 60, 55-63. https://doi.org/10.1111/j.1365-2389.2008.01089.x

Brevik, E.C., 2012. Soils and climate change: gas fluxes and soil processes. Soil Horizons 53(4), 12-23. https://doi.org/10.2136/sh12-04-0012

Chen, C.R., Condron, L.M., Xu, Z.H., 2008. Impacts of grassland afforestation with coniferous trees on soil phosphorus dynamics and associated microbial processes: a review. Forest Ecology and Management 255, 396-409. https://doi.org/10.1016/j.foreco.2007.10.040

Choi, W.II, Moorhead, D.L., Neher, D.A., Ryoo, M.II, 2006. A modeling study of soil temperature and moisture effects on population dynamics of Paronychiurus kimi (Collembola: Onychiuridae). Biology and Fertility of Soils 43, 69-75. https://doi.org/10.1007/s00374-005-0062-5

Cluzeau, D., Guernion, M., Chaussod, R., Martin-Laurent, F., Villenave, C., Cortet, J., Ruiz-Camacho, N., Pernin, C., Mateille, T., Philippot, L., Bellido, A., Rougé, L., Arrouays, D., Bispo, A., Pérès, G., 2012. Integration of biodiversity in soil quality monitoring: baselines for microbial and soil fauna parameters for different land-use types. 
European Journal of Soil Biology 49, 63-72. https://doi.org/10.1016/ j.ejsobi.2011.11.003

Coleman, D.C., Wall, D.H., 2015. Soil fauna: occurrence, biodiversity, and roles in ecosystem function. Chapter 5. [In:] Paul, E.A. (Ed.), Soil microbiology, ecology, and biochemistry; $4^{\text {th }}$ ed. Academic Press, New York, 111-149. https://doi.org/10.1016/B978-0-12-415955-6.00005-0

CONAF (Corporación Nacional Forestal, CL), 2011. Catastro de los recursos vegetacionales nativos de Chile: monitoreo de cambios y actualizaciones período 1997-2011. Santiago, Chile.

CONAF (Corporación Nacional Forestal, CL), 2009. Plan de manejo Reserva Nacional Coyhaique. Reserva Nacional Coyhaique.

Cortet, J., Gomot-De Vauflery, A., Poinsot-Balaguer, N., Gomot, L., Texier, C., Cluzeau, D., 1999. The use of invertebrate soil fauna in monitoring pollutant effects. European Journal of Soil Biology 35, 115-134. https://doi.org/10.1016/S1164-5563(00)00116-3

da Silva, P.M., Carvalho, F., Dirilgen, T., Stone, D., Cramer, R., Bolger, T., Sousa, J.P., 2016. Traits of collembolan life-form indicate land use types and soil properties across an European transect. Applied Soil Ecology 97, 66-77. https://doi.org/10.1016/j.apsoil.2015.07.018

Dumas, J.B.A., 1831. Procédés de l'analyse organique. Annales de chimie et de physique $247,198-213$.

Elo, R.A., Sorvari, J., 2019. The impacts of forest clear felling on the oribatid mite fauna inhabiting Formica aquilonia nest mounds. European Journal of Soil Biology 94, 103101. https://doi.org/10.1016/ j.ejsobi.2019.103101

Fajardo, A., Piper, F.I., 2015. High foliar nutrient concentrations and resorption efficiency in Embothrium coccineum (Proteaceae) in southern Chile. American Journal of Botany 102, 208-216. https://doi. org/10.3732/ajb.1400533

Fantappiè, M., L’Abate, G., Costantini, E.A.C., 2010. Factors influencing soil organic carbon variations in Italy during the last three decades. [In:] Zdruli, P., Pagliai, S., Kapur, M., Faz Cano, P. (Eds.), Land degradation and desertification: assessment, mitigation and remediation. Springer Science + Business Media B.V., 435-465.

Galli, L., 2020. An user friendly tool to assess the effects on agricultural soils of different practices: the QBS-ar index. Modern Concepts and Developments in Agronomy 6(5), 680-682. https://doi.org/10.31031/ MCDA.2020.06.000648

Galli, L., Bonacchi, A., Capurro, M., Conti, I., Crovetto, F., Ferrari, C., Conti, F.D., Menta, C., 2015. Assessment of the trampling impact on soil Arthropoda in a Mediterranean habitat. Acta Societatis Zoologicae Bohemicae 79(3), 193-198. https://doi.org/10.13140/RG.2.1.2113.5122

Galli, L., Capurro, M., Menta, C., Rellini, I., 2014. Is the QBS-ar index a good tool to detect the soil quality in Mediterranean areas? A cork tree Quercus suber L. (Fagaceae) wood as a case of study. Italian Journal of Zoology 81(1), 126-135. https://doi.org/10.1080/11250003.2013.875601

Galli, L., Capurro, M., Molyneux, T., Torti, C., Zinni, M., 2019. Ecology of Italian Protura. Pedobiologia 73, 20-28. https://doi.org/10.1016/ j.pedobi.2019.01.004

Gardi, C., Angelini, M., Barceló, S., Comerma, J., Cruz Gaistardo, C., Encina Rojas, A., Jones, A., Krasilnikov, P., Mendonça Santos Brefin, M.L., Montanarella, L., Muńiz Ugarte, O., Schad, P., Vara Rodríguez, M.I., Vargas, R., Ravina da Silva, M. (Eds.), 2015. Soil atlas of Latin America and the Caribbean. European Commission - Publications Office of the European Union, L-2995 Luxembourg.

Gonçalves, F., Nunes, C., Carlos, C., López, Á., Oliveira, I., Crespí, A., Teixeira, B., Pinto, R., Costa, C.A., Torres, L., 2020. Do soil management practices affect the activity density, diversity, and stability of soil arthropods in vineyards? Agriculture Ecosystems \& Environment 294, 106863. https://doi.org/10.1016/j.agee.2020.106863

Gundale, M.J., Sutherland, S., DeLuca, T.H., 2008. Fire, native species, and soil resource interactions influence the spatio-temporal invasion pattern of Bromus tectorum. Ecography 31, 201-210. https://doi. org/10.1111/j.0906-7590.2008.5303.x

Hammer, Ø., Harper, D.A.T., Ryan, P.D., 2001. PAST: Paleontological sta- tistics software package for education and data analysis. Palaeontologia Electronica 4, 1-9. http://palaeo-electronica.org/2001_1/past/issue1_01.htm

Hartley, W., Uffindell, L., Plumb, A., Rawlinson, H.A., Putwain, P., Dickinson, N.M., 2008. Assessing biological indicators for remediated anthropogenic urban soils. Science of The Total Environment 405, 358-369. https://doi.org/10.1016/j.scitotenv.2008.06.004

Hasegawa, M., 2002. The response of collembolan community to the amount and composition of organic matter of a forest floor. Pedobiologia 46, 353-364. https://doi.org/10.1078/0031-4056-00143

Hopkin, S.P., 1997. Biology of the Springtails (Insecta: Collembola). Oxford University Press.

IUSS Working Group WRB, 2014. World Reference Base for Soil Resources 2014. International soil classification system for naming soils and creating legends for soil maps. World Soil Resources Reports No. 106. FAO, Rome.

Kerven, G.L., Menzies, N.W., Geyer, M.D., 2000. Analytical methods and quality assurance. Soil carbon determination by high temperature combustion - a comparison with dichromate oxidation procedures and the influence of charcoal and carbonate carbon on the measured value. Communications in Soil Science and Plant Analysis 31, 1935-1939. https://doi.org/10.1080/00103620009370551

Kotroczó, Z., Juhos, K., Biró, B., Kocsis, T., Pabar, S.A., Varga, C., Fekete I., 2020. Effect of detritus manipulation on different organic matter decompositions in temperate deciduous forest soils. Forests 11(6), 675. https://doi.org/10.3390/f11060675

Laiho, R., Silvan, N., Cárcamo, H., Vasander, H., 2001. Effects of water level and nutrients on spatial distribution of soil mesofauna in peatlands drained for forestry in Finland. Applied Soil Ecology 16, 1-9. https://doi.org/10.1016/S0929-1393(00)00103-7

Lajtha, K., Bowden, R.D., Crow, S., Fekete, I., Kotroczó, Z., Plante, A., Simpson, M.J., Nadelhoffer, K.J., 2018. The detrital input and removal treatment (DIRT) network: insights into soil carbon stabilization. Science of the Total Environment 640-641, 1112-1120. https://doi.org/10.1016/ j.scitotenv.2018.05.388

Lal, R., 2004. Soil carbon sequestration impacts on global climate change and food security. Science 304, 1623-1627. https://doi.org/10.1126/science.1097396

Lavelle, P., Decaëns, T., Aubert, M., Barot, S., Blouin, M., Bureau, F., Margerie, P., Mora, P., Rossi, J.-P., 2006. Soil invertebrates and ecosystem services. European Journal of Soil Biology 42, S3-S15. https://doi. org/10.1016/j.ejsobi.2006.10.002

Loranger, G., Bandyopadhyaya, I., Razaka, B., Ponge, J.-F., 2001. Does soil acidity explain altitudinal sequences in collembolan communities? Soil Biology and Biochemistry 33, 381-393. https://doi.org/10.1016/ S0038-0717(00)00153-X

Madej, G., Barczyk, G., Gdawiec, M., 2011. Evaluation of Soil Biological Quality Index (QBS-ar): its sensitivity and usefulness in the post-mining chronosequence - preliminary research. Polish Journal of Environmental Studies 20(5), 1367-1372.

Maraun, M., Scheu, S., 2000. The structure of oribatid mites communities (Acari, Oribatida): patterns, mechanisms and implications for future research. Ecography 23(3), 374-382. https://doi.org/10.1111/j.16000587.2000.tb00294.x

Mazzoncini, M., Canali, S., Giovannetti, M., Castagnoli, M., Tittarelli, F., Antichi, D., Nannelli, R., Cristiani, C., Bàrberi, P., 2010. Comparison of organic and conventional stockless arable systems: a multidisciplinary approach to soil quality evaluation. Applied Soil Ecology 44, 124-132. https://doi.org/10.1016/j.apsoil.2009.11.001

Menta, C., Conti, F.D., Pinto, S., Bodini, A., 2018. Soil biological quality index QBS-ar: 15 years of application at global scale. Ecological Indicators 85, 773-780. https://doi.org/10.1016/j.ecolind.2017.11.030

Menta, C., Leoni, A., Gardi, C., Conti, D., 2011. Are grasslands important habitats for soil microarthropod conservation? Biodiversity Conservation 20, 1073-1087. https://doi.org/10.1007/s10531-011-0017-0 
Menta, C., Remelli, S., 2020. Soil health and arthropods: from complex system to worthwhile investigation. Insects 11, 54. https://doi. org/10.3390/insects11010054

Minor, M.A., 2008. Protura in native and exotic forests in the North Island of New Zealand. New Zealand Journal of Zoology 35, 271-279. https:// doi.org/10.1080/03014220809510124

MIPAF, 2000. Osservatorio nazionale pedologico e per la qualità del suolo, International Society of Soil Science, Società Italiana della Scienza del Suolo. Metodi di analisi chimica del suolo, F. Angeli, Milano.

Moço, M.K.S., Gama-Rodrigues, E.F., Gama-Rodrigues, A.C., Machado, R.C.R., Baligar, V.C., 2010. Relationships between invertebrate communities, litter quality and soil attributes under different cacao agroforestry systems in the south of Bahia, Brazil. Applied Soil Ecology 46, 347-354. https://doi.org/10.1016/j.apsoil.2010.10.006

Murphy, B.W., 2014. Soil Organic Matter and Soil Function. Review of the Literature and Underlying Data. Department of the Environment, Canberra, Australia.

Nelson, D.W, Sommers, L.E., 1996. Total carbon, organic carbon, and organic matter. [In:] Sparks, D.L., Page, A.L., Helmke, P.A., Loeppert, R.H., Soltanpour, P.N., Tabatabai, M.A., Johnston, C.T., Sumner, M.E. (Eds.), Methods of soil analysis. Part 3. Chemical methods. Soil Science Society of America Book Series no. 5, 961-1010. https://doi. org/10.2136/sssabookser5.3.c34

Olsen, S.R., Cole, C.V., Watanabe, F.S., Dean, L.A., 1954. Estimation of available phosphorus in soils by extraction with sodium bicarbonate. USDA circular 939, U.S. Gov. Print. Office, Washington, DC.

Ondrasek, G., Bakić Begić, H., Zovko, M., Filipović, L., Meriño-Gergichevich, C., Savić, R., Rengel, Z., 2019. Biogeochemistry of soil organic matter in agroecosystems \& environmental implications. Science of The Total Environment 658, 1559-1573. https://doi.org/10.1016/ j.scitotenv.2018.12.243

Orgiazzi, A., Bardgett, R.D., Barrios, E., Behan-Pelletier, V., Briones, M.J.I., Chotte, J-L., De Deyn, G.B., Eggleton, P., Fierer, N., Fraser, T., Hedlund, K., Jeffery, S., Johnson, N.C., Jones, A., Kandeler, E., Kaneko, N., Lavelle, P., Lemanceau, P., Miko, L., Montanarella, L., Moreira, F.M.S., Ramirez, K.S., Scheu, S., Singh, B.K., Six, J., van der Putten, W.H., Wall, D.H. (Eds.), 2016. Global soil biodiversity atlas. European Commission, Publications Office of the European Union, Luxembourg.

Paoletti, M.G., 1999. The role of earthworms for assessment of sustainability and as bioindicators. Agriculture, Ecosystems \& Environment 74, 137-155. https://doi.org/10.1016/S0167-8809(99)00034-1

Paoletti, M.G., Hassall, M., 1999. Woodlice (Isopoda: Oniscidea): their potential for assessing sustainability and use as bioindicators. Agriculture, Ecosystems \& Environment 74, 157-165. https://doi.org/10.1016/ S0167-8809(99)00035-3

Parisi, V., 2001. La qualità biologica del suolo. Un metodo basato sui microartropodi. Acta Naturalia de l'Ateneo Parmense 37, 105-114.

Parisi, V., Menta, C., 2008. Microarthropods of the soil: convergence phenomena and evaluation of soil quality using QBS-ar and QBS-c. Fresenius Environmental Bulletin 17(8b), 1170-1174.

Parisi, V., Menta, C., Gardi, C., Jacomini, C., Mozzanica, E., 2005. Microarthropod community as a tool to asses soil quality and biodiversity: a new approach in Italy. Agriculture, Ecosystems \& Environment 105, 323-333. https://doi.org/10.1016/j.agee.2004.02.002

Paustian, K., Andrén, O., Janzen, H.H., Lal, R., Smith, P., Tian, G., Tiessen, H., Van Noordwijk, M., Woomer, P.L., 1997. Agricultural soils as a sink to mitigate $\mathrm{CO}_{2}$ emissions. Soil Use and Management 13, 230-244. https://doi.org/10.1111/j.1475-2743.1997.tb00594.x

Piper, F.I., Baeza, G., Zúñiga-Feest, A., Fajardo, A., 2013. Soil nitrogen, and not phosphorus, promotes cluster-root formation in a South American Proteaceae, Embothrium coccineum. American Journal of Botany 100, 2328-2338. https://doi.org/10.3732/ajb.1300163

Potapov, A.M., Goncharov, A.A., Semenina, E.E., Yu Korotkevich, A., Tsurikov, S.M., Rozanova, O.L., Anichkin, A.E., Zuev, A.G., Samoylova E.S., Semenyuk, I.I., Yevdokimov, I.V., Tiunov, A.V., 2017 Arthropods in the subsoil: abundance and vertical distribution as related to soil organic matter, microbial biomass and plant roots. European Journal of Soil Biology 82, 88-97. https://doi.org/10.1016/j.ejsobi.2017.09.001

Rendoš, M., Raschmanová, N., Kováč, L., Miklisová, D., Mock, A., Luuptáčik, P., 2016. Organic carbon content and temperature as substantial factors affecting diversity and vertical distribution of Collembola on forested scree slopes. European Journal of Soil Biology 75, 180-187. https://doi.org/10.1016/j.ejsobi.2016.06.001

Ruiz Sinoga, J.D., Pariente, S., Romero Diaz, A., Martinez Murillo, J.F., 2011. Variability of relationships between soil organic carbon and some soil properties in Mediterranean rangelands under different climatic conditions (South of Spain). Catena 94, 17-25. https://doi. org/10.1016/j.catena.2011.06.004

Salmon, S., Artuso, N., Frizzera, L., Zampedri, R., 2008. Relationships between soil fauna communities and humus forms: response to forest dynamics and solar radiation. Soil Biology and Biochemistry 40, 1707-1715. https://doi.org/10.1016/j.soilbio.2008.02.007

Santorufo, L., Van Gestel, C.A.M., Rocco, A., Maisto, G., 2012. Soil invertebrates as bioindicators of urban soil quality. Environmental Pollution 161, 57-63. https://doi.org/10.1016/j.envpol.2011.09.042

Sapkota, T.B., Mazzoncini, M., Bàrberi, P., Antichi, D., Silvestri, N., 2012. Fifteen years of no till increase soil organic matter, microbial biomass and arthropod diversity in cover crop-based arable cropping systems. Agronomy for Sustainable Development 32, 853-863. https:// doi.org/10.1007/s13593-011-0079-0

Staley, J.T., Hodgson, C.J., Mortimer, S.R., Morecroft, M.D., Masters, G.J., Brown, V.K., Taylor, M.E., 2007. Effects of summer rainfall manipulations on the abundance and vertical distribution of herbivorous soil macro-invertebrates. European Journal of Soil Biology 43, 189-198. https://doi.org/10.1016/j.ejsobi.2007.02.010

Tabaglio, V., Gavazzi, C., Menta, C., 2009. Physico-chemical indicators and microarthropod communities as influenced by no-till, conventional tillage and nitrogen fertilisation after four years of continuous maize. Soil and Tillage Research 105, 135-142. https://doi.org/10.1016/ j.still.2009.06.006

Tan, Z., Lal, R.,. Smeck, N.E, Calhoun, F.G., Slater, B.K., Parkinson, B., Gehring, R.M., 2004. Taxonomic and geographic distribution of soil organic carbon pools in Ohio. Soil Science Society of America Journal 68, 1896-1904. https://doi.org/10.2136/sssaj2004.1896

van Straalen, N.M., 2004. The use of soil invertebrates in ecological survey of contaminated soils. [In:] Doelman, P., Eijsackers, H.J.P. (Eds.), Vital soil function, value and properties. Elsevier, Amsterdam, 159-194.

Visioli, G., Menta, C., Gardi, C., Conti, F.D., 2013. Metal toxicity and biodiversity in serpentine soils: application of bioassay tests and microarthropod index. Chemosphere 90 (3), 1267-1273. https://doi. org/10.1016/j.chemosphere.2012.09.081

Wardle, D.A., 2002. Linking the aboveground and belowground components. Monographs in Population Biology. Princeton University Press.

Wissuwa, J., Salamon, J.-A., Frank, T., 2013. Oribatida (Acari) in grassy arable fallows are more affected by soil properties than habitat age and plant species. European Journal of Soil Biology 59, 8-14. https://doi. org/10.1016/j.ejsobi.2013.08.002

Wolters, V., 2001. Biodiversity of soils animals and its function. European Journal of Soil Biology 37, 221-227. https://doi.org/10.1016/S11645563(01)01088-3

Wu, P., Liu, X., Liu, S., Wang, J., Wang, Y., 2014. Composition and spatio-temporal variation of soil microarthropods in the biodiversity hotspot of northern Hengduan Mountains, China. European Journal of Soil Biology 62, 30-38. https://doi.org/10.1016/j.ejsobi.2014.02.013

Zucca, C., Canu, A., Previtali, F., 2010. Soil degradation by land use change in an agropastoral area in Sardinia (Italy). Catena 83, 46-54. https:// doi.org/10.1016/j.catena.2010.07.003

website 1: https://climatologia.meteochile.gob.cl/application (accessed 10.06.2020) 
Appendix 1

Soil microarthropods collected in four habitats in Coyhaique Natural Reserve (Chile) on eight sampling dates

\begin{tabular}{|c|c|c|c|c|c|c|c|c|}
\hline Date & 13.10 & 23.10 & 02.11 & 14.11 & 24.11 & 06.12 & 18.12 & 15.01 \\
\hline \multicolumn{9}{|l|}{ Anthropogenic grassland } \\
\hline Aranea & 1 & 2 & 2 & 22 & 0 & 5 & 1 & l \\
\hline Acarina & 172 & 154 & 356 & 494 & 350 & 226 & 420 & l \\
\hline Isopoda & 0 & 0 & 0 & 0 & 0 & 0 & 0 & l \\
\hline Diplopoda & 0 & 0 & 0 & 0 & 0 & 0 & 0 & l \\
\hline Pauropoda & 0 & 0 & 0 & 0 & 0 & 0 & 0 & l \\
\hline Symphyla & 0 & 0 & 0 & 0 & 0 & 0 & 0 & 1 \\
\hline Chilopoda Lithobiomorpha & 0 & 0 & 0 & 0 & 0 & 1 & 0 & l \\
\hline Chilopoda Geofilomorpha & 0 & 0 & 0 & 0 & 0 & 0 & 1 & l \\
\hline Protura & 0 & 0 & 0 & 0 & 0 & 0 & 0 & l \\
\hline Diplura & 0 & 0 & 0 & 0 & 0 & 10 & 0 & l \\
\hline Collembola & 436 & 474 & 159 & 177 & 181 & 25 & 312 & 1 \\
\hline Dermaptera & 0 & 0 & 0 & 7 & 0 & 0 & 0 & 1 \\
\hline Blattodea & 0 & 0 & 0 & 0 & 0 & 1 & 0 & l \\
\hline Psocoptera & 0 & 0 & 2 & 5 & 4 & 1 & 0 & l \\
\hline Hemiptera & 0 & 1 & 1 & 0 & 9 & 5 & 1 & 1 \\
\hline Thysanoptera & 1 & 0 & 2 & 136 & 23 & 30 & 4 & 1 \\
\hline Coleoptera & 5 & 4 & 13 & 8 & 2 & 16 & 1 & 1 \\
\hline Coleoptera larvae & 0 & 0 & 11 & 12 & 8 & 6 & 38 & l \\
\hline Hymenoptera (Formicidae excluded) & 3 & 0 & 3 & 0 & 0 & 0 & 5 & l \\
\hline Formicidae & 0 & 1 & 2 & 2 & 0 & 1 & 0 & l \\
\hline Diptera (larvae) & 31 & 10 & 13 & 15 & 10 & 1 & 18 & l \\
\hline Other Holometabola (larvae) & 1 & 0 & 1 & 2 & 3 & 22 & 0 & 1 \\
\hline Other Holometabola (adults) e.g. Diptera & 31 & 4 & 23 & 17 & 36 & 11 & 9 & l \\
\hline Number of taxa & 9 & 8 & 13 & 12 & 10 & 15 & 11 & l \\
\hline Number of specimens & 681 & 650 & 588 & 897 & 626 & 361 & 810 & l \\
\hline \multicolumn{9}{|l|}{ Reforestation pine forest } \\
\hline Aranea & 1 & 2 & 1 & 1 & 4 & 3 & 0 & 0 \\
\hline Acarina & 71 & 24 & 153 & 257 & 145 & 151 & 106 & 165 \\
\hline Isopoda & 0 & 0 & 0 & 0 & 0 & 0 & 0 & 0 \\
\hline Diplopoda & 0 & 0 & 0 & 0 & 0 & 0 & 3 & 0 \\
\hline Pauropoda & 0 & 0 & 0 & 0 & 0 & 0 & 0 & 0 \\
\hline Symphyla & 0 & 0 & 0 & 0 & 0 & 0 & 0 & 0 \\
\hline Chilopoda Lithobiomorpha & 0 & 0 & 0 & 0 & 0 & 0 & 0 & 0 \\
\hline Chilopoda Geofilomorpha & 0 & 22 & 0 & 4 & 0 & 0 & 2 & 0 \\
\hline Protura & 0 & 0 & 0 & 0 & 0 & 0 & 0 & 0 \\
\hline Diplura & 0 & 0 & 0 & 0 & 0 & 0 & 0 & 0 \\
\hline Collembola & 247 & 14 & 56 & 104 & 15 & 51 & 265 & 86 \\
\hline Dermaptera & 0 & 0 & 0 & 0 & 0 & 0 & 0 & 1 \\
\hline
\end{tabular}


Appendix 1 - continue

\begin{tabular}{|c|c|c|c|c|c|c|c|c|}
\hline Date & 13.10 & 23.10 & 02.11 & 14.11 & 24.11 & 06.12 & 18.12 & 15.01 \\
\hline Blattodea & 0 & 0 & 0 & 0 & 0 & 0 & 0 & 0 \\
\hline Psocoptera & 0 & 0 & 3 & 5 & 0 & 0 & 0 & 3 \\
\hline Hemiptera & 0 & 0 & 0 & 1 & 0 & 0 & 0 & 5 \\
\hline Thysanoptera & 0 & 0 & 0 & 0 & 0 & 1 & 1 & 3 \\
\hline Coleoptera & 0 & 1 & 2 & 1 & 1 & 4 & 2 & 8 \\
\hline Coleoptera larvae & 1 & 2 & 3 & 2 & 3 & 1 & 1 & 5 \\
\hline Hymenoptera (Formicidae excluded) & 0 & 0 & 13 & 3 & 0 & 0 & 1 & 12 \\
\hline Formicidae & 0 & 0 & 0 & 1 & 4 & 0 & 0 & 1 \\
\hline Diptera (larvae) & 17 & 15 & 52 & 7 & 19 & 11 & 14 & 22 \\
\hline Other Holometabola (larvae) & 1 & 0 & 0 & 0 & 3 & 1 & 0 & 1 \\
\hline Other Holometabola (adults) e.g. Diptera & 3 & 5 & 167 & 54 & 33 & 7 & 12 & 85 \\
\hline Number of taxa & 7 & 8 & 9 & 12 & 9 & 9 & 10 & 13 \\
\hline Number of specimens & 341 & 85 & 450 & 440 & 227 & 230 & 407 & 397 \\
\hline \multicolumn{9}{|c|}{ Native forest of secondary growth after fires } \\
\hline Aranea & 2 & 2 & 5 & 3 & 0 & 4 & 1 & 1 \\
\hline Acarina & 135 & 225 & 1193 & 330 & 477 & 2107 & 359 & 451 \\
\hline Isopoda & 1 & 0 & 0 & 0 & 0 & 0 & 0 & 0 \\
\hline Diplopoda & 0 & 0 & 0 & 0 & 0 & 0 & 0 & 0 \\
\hline Pauropoda & 0 & 0 & 0 & 0 & 0 & 0 & 1 & 0 \\
\hline Symphyla & 0 & 0 & 0 & 0 & 0 & 25 & 0 & 0 \\
\hline Chilopoda Lithobiomorpha & 0 & 0 & 0 & 0 & 0 & 0 & 0 & 0 \\
\hline Chilopoda Geofilomorpha & 6 & 3 & 6 & 8 & 2 & 17 & 3 & 2 \\
\hline Protura & 0 & 0 & 0 & 3 & 5 & 29 & 0 & 1 \\
\hline Diplura & 0 & 0 & 0 & 0 & 0 & 0 & 0 & 0 \\
\hline Collembola & 63 & 93 & 287 & 234 & 85 & 768 & 73 & 139 \\
\hline Dermaptera & 0 & 0 & 0 & 0 & 0 & 0 & 0 & 0 \\
\hline Blattodea & 0 & 0 & 0 & 0 & 0 & 0 & 0 & 0 \\
\hline Psocoptera & 0 & 2 & 22 & 3 & 3 & 1 & 0 & 2 \\
\hline Hemiptera & 0 & 0 & 0 & 0 & 0 & 2 & 0 & 0 \\
\hline Thysanoptera & 0 & 0 & 0 & 2 & 0 & 1 & 0 & 0 \\
\hline Coleoptera & 2 & 5 & 10 & 5 & 1 & 9 & 6 & 1 \\
\hline Coleoptera larvae & 2 & 11 & 10 & 8 & 1 & 22 & 1 & 1 \\
\hline Hymenoptera (Formicidae excluded) & 0 & 1 & 1 & 1 & 0 & 4 & 9 & 2 \\
\hline Formicidae & 0 & 0 & 0 & 0 & 0 & 0 & 0 & 0 \\
\hline Diptera (larvae) & 15 & 22 & 53 & 28 & 25 & 13 & 7 & 11 \\
\hline Other Holometabola (larvae) & 5 & 0 & 0 & 3 & 1 & 0 & 0 & 0 \\
\hline Other Holometabola (adults) e.g. Diptera & 2 & 8 & 196 & 9 & 6 & 12 & 325 & 12 \\
\hline Number of taxa & 10 & 10 & 10 & 13 & 10 & 14 & 10 & 11 \\
\hline Number of specimens & 233 & 372 & 1783 & 637 & 606 & 3014 & 785 & 623 \\
\hline
\end{tabular}


Appendix 1 - continue

\begin{tabular}{|c|c|c|c|c|c|c|c|c|}
\hline Date & 13.10 & 23.10 & 02.11 & 14.11 & 24.11 & 06.12 & 18.12 & 15.01 \\
\hline \multicolumn{9}{|l|}{ Primary native forest } \\
\hline Aranea & 0 & 31 & 16 & 6 & 4 & 3 & 1 & 7 \\
\hline Acarina & 22 & 2520 & 271 & 278 & 120 & 449 & 44 & 395 \\
\hline Isopoda & 1 & 4 & 4 & 0 & 0 & 1 & 0 & 0 \\
\hline Diplopoda & 0 & 0 & 0 & 0 & 0 & 0 & 0 & 0 \\
\hline Pauropoda & 0 & 2 & 0 & 0 & 0 & 4 & 0 & 1 \\
\hline Symphyla & 0 & 0 & 0 & 0 & 1 & 0 & 0 & 0 \\
\hline Chilopoda Lithobiomorpha & 0 & 0 & 0 & 0 & 0 & 0 & 0 & 0 \\
\hline Chilopoda Geofilomorpha & 3 & 14 & 11 & 2 & 7 & 6 & 4 & 1 \\
\hline Protura & 0 & 10 & 1 & 3 & 3 & 12 & 0 & 1 \\
\hline Diplura & 0 & 0 & 0 & 0 & 0 & 0 & 0 & 0 \\
\hline Collembola & 61 & 421 & 107 & 126 & 73 & 135 & 22 & 102 \\
\hline Dermaptera & 0 & 0 & 0 & 0 & 0 & 0 & 0 & 0 \\
\hline Blattodea & 0 & 0 & 0 & 0 & 0 & 0 & 0 & 0 \\
\hline Psocoptera & 0 & 2 & 1 & 0 & 0 & 1 & 0 & 11 \\
\hline Hemiptera & 0 & 0 & 0 & 0 & 2 & 1 & 0 & 1 \\
\hline Thysanoptera & 0 & 2 & 1 & 4 & 0 & 1 & 0 & 6 \\
\hline Coleoptera & 2 & 17 & 19 & 2 & 18 & 10 & 4 & 19 \\
\hline Coleoptera larvae & 5 & 44 & 12 & 7 & 5 & 8 & 6 & 12 \\
\hline Hymenoptera (Formicidae excluded) & 0 & 6 & 5 & 0 & 8 & 1 & 1 & 14 \\
\hline Formicidae & 0 & 0 & 0 & 0 & 1 & 0 & 3 & 0 \\
\hline Diptera (larvae) & 33 & 50 & 23 & 37 & 7 & 14 & 25 & 35 \\
\hline Other Holometabola (larvae) & 2 & 2 & 0 & 0 & 7 & 0 & 8 & 0 \\
\hline Other Holometabola (adults) e.g. Diptera & 0 & 102 & 42 & 11 & 196 & 6 & 5 & 71 \\
\hline Number of taxa & 8 & 15 & 13 & 10 & 14 & 15 & 11 & 14 \\
\hline Number of specimens & 129 & 3227 & 513 & 476 & 452 & 652 & 123 & 676 \\
\hline
\end{tabular}

